\title{
ДОСЛІДЖЕННЯ МОЖЛИВОСТІ ВИКОРИСТАННЯ ZOSTERA MARINA У ЯКОСТI АЛЬТЕРНАТИВНОЇ СИРОВИНИ ЦЕЛЮЛОЗНО-ПАПЕРОВОЇ ПРОМИСЛОВОСТІ
}

\author{
Д.С. Лобунець ${ }^{1}$, С.В. Артемцова ${ }^{2}$, О.В. Павленко ${ }^{2}$, М.Ю. Мечик ${ }^{1}$ \\ ${ }^{1}$ Шосткинська спеціалізована школа I-III ступенів №1 \\ вул. Чернігівська, 10, Шостка, 41100, Україна \\ ${ }^{2}$ Шосткинський інститут Сумського державного університету \\ вул. Гагаріна, 1, Шостка, 41100, Україна \\ e-mail: daria.lobunets@ gmail.com
}

Основною сировиною для отримання паперу є целюлоза, яка $є$ природним полімером $\mathrm{i}$ головною складовою оболонки рослинних клітин. Механічна міцність в поєднанні 3 еластичністю роблять целюлозу найкращим варіантом для виробництва різноманітного пакувального паперу, картону та звичайного паперу, 3 якого виробляються зошити та підручники. Але, зважаючи на постійне зростання вирубки лісів, необхідно знайти більш екологічний спосіб отримання сировини для целюлозно-паперової промисловості [1].

В Україні тривають пошуки нової сировини для виробництва паперу. Так у міжнародному співробітництві було розроблено технологію виготовлення екологічно чистого паперу 3 соломи [2]. У Національному технічному університету «КПІ» розробили технологію виготовлення пакувального паперу із стебел соняшнику [3]. Інститутом луб'яних культур у м. Глухів під керівництвом Української академії аграрних наук був розроблений інноваційний проект $100 \%$ безвідходного екологічно чистого виробництва паперу 3 використанням технічних конопель у якості целюлозної сировини [4]. Також в Україні розпочали виробництво eco-friendly паперу 3 опалого листя. Технологію запропонував молодий науковець Валентин Фречка [5].

Одним з замінників деревини у паперовій промисловості можуть бути викинуті штормом на берег бурі водорості. На сьогоднішній день виготовлення добрив та кормових добавок 3 водоростей набирає оберти, адже це не шкодить навколишньому середовищу, а навпаки приносить користь, бо хвилі забирають викинуті та підгнилі водорості назад в море чи океан і відбувається вторинне забруднення води. Встановлено [6] що бурі водорості містять до 17\% водоростевої целюлози, яка за своєю будовою близька до целюлози вищих рослин, i, таким чином, $є$ iï потенційним джерелом. Використання сухих бурих водоростей, які можна розглядати як недеревні целюлозовмісні відходи, дає змогу розширити сировинну базу для отримання паперово-целюлозної продукції.

Камка - Zostera marina - зростає на мілководді по всьому узбережжю Чорного та Азовського морів. Вона щороку виноситься на берег хвилями і у великій кількості накопичується щільним 
шаром на береговій лінії. Її хімічний склад це: $45 \%$ білка, $35 \%$ вуглеводів, $10 \%$ ліпідів. У склад також входить йод, залізо, цинк, мідь і кобальт. Окрім того, в ній міститься значна кількість вітамінів і біологічно активних речовин. І одна з цих речовин - дуже незвичайний полісахарид фукоїдан, який має властивість протипухлинної дії на організм людини, укріплює імунну систему, надає лікувальну дію на суглоби, володіє протизапальним і противірусним ефектом і ще багатьма іншими дуже позитивними властивостями.

Зважаючи на вище перераховані особливості морської трави, особливу увагу привертає можливість використання берегових покладів Zostera marina для отримання пакувального паперу для харчової промисловості. Наприклад для тривалого зберігання фруктів у свіжому вигляді застосовуються пакувальні матеріали, що містять фунгіциди, які захищають від враження плісеневими грибами, речовини [7]. Камкові ж матеріали не потребують обробки додатковими фунгіцидами.

За результати літературного пошуку є актуальним дослідження можливості отримання паперу з камки Zostera marina на основі вивчення наукових розробок та інших наукових матеріалів. Це може знайти застосування для отримання целюлозно-паперової продукції спеціального призначення, вогнетривкої, такої що має антисептичні властивості, для пакування продуктів, що мають подовжений строк зберігання або одноразового посуду. Також шляхом переробки камкової маси можливе виробництво наповнювачів в синтетичні полімери, що забезпечують біологічну руйнівність полімерних композицій і необхідних при виробництві матеріалів 3 регульованим терміном служби, а також для отримання целюлозних напівфабрикатів, використовуваних в якості сировини для хімічної промисловості. 3 метою досягнення поставлених цілей, а саме отримання зразків паперової продукції з морської трави Zostera marina в лабораторних умовах, було проведено серію експериментів з варіюванням технологічних параметрів процесу на рівні малого об'єму. На основі проведених експериментів розроблено попередній план дослідження.

За основу процесу було узято стандартну технологію отримання паперової маси з деревини [8]. Процес включає попереднє промивання камки, підсушування до постійної маси за кімнатної температури, механічне подрібнення волокон, обробку гарячою водою до утворення однорідної суміші. Після проведення цих операцій було отримано папероподібний матеріал бурого кольору. Для освітлення матеріалу було розглянуто такі реагенти, як гіпохлорит натрію, хлорне вапно та пероксид водню. 3 метою створення безвідходної екологічної технології у якості відбілюючого агента обрано пероксид водню. Використання цього реактиву було досліджено для водоростей типу Cladophora, Posidonia, Ulva у розробці дослідницької групи ECOWAL з Університету Пабло де Олавиде в Севільї [9]. Тому $є$ доцільним використовувати його для освітлення паперової маси з камки Zostera marina.

У якості об'єкту дослідження використовували суха Zostera Marina, зібрана на узбережжі Каркінітської затоки. Вони являють собою пружню суміш стрічкоподібного листя бурого кольору.

В лабораторних умовах було об'єднано процеси розпуску подрібненої сировини у воді та відбілювання паперової маси. 

«Екологія. Людина. Суспільство» (м. Київ, Україна, 2021 р.)

На рисунках 1-6 представлено послідовність операцій отримання зразків паперу в лабораторних умовах.

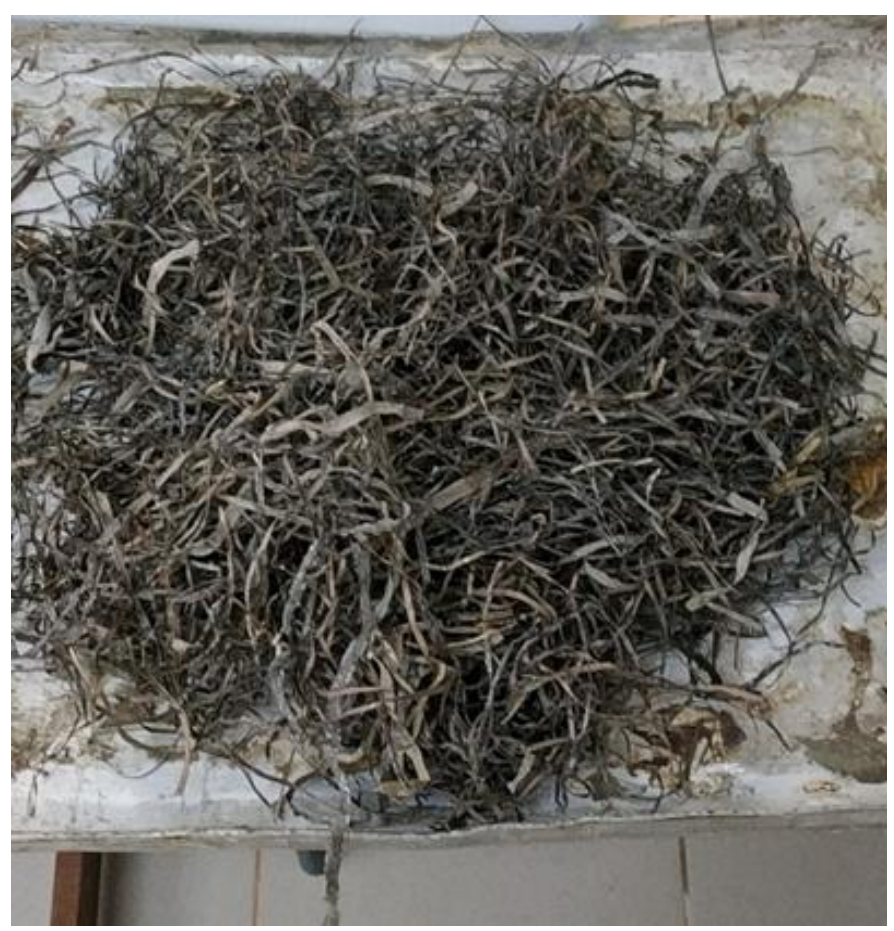

Рисунок 1. Промита маса Zostera marina

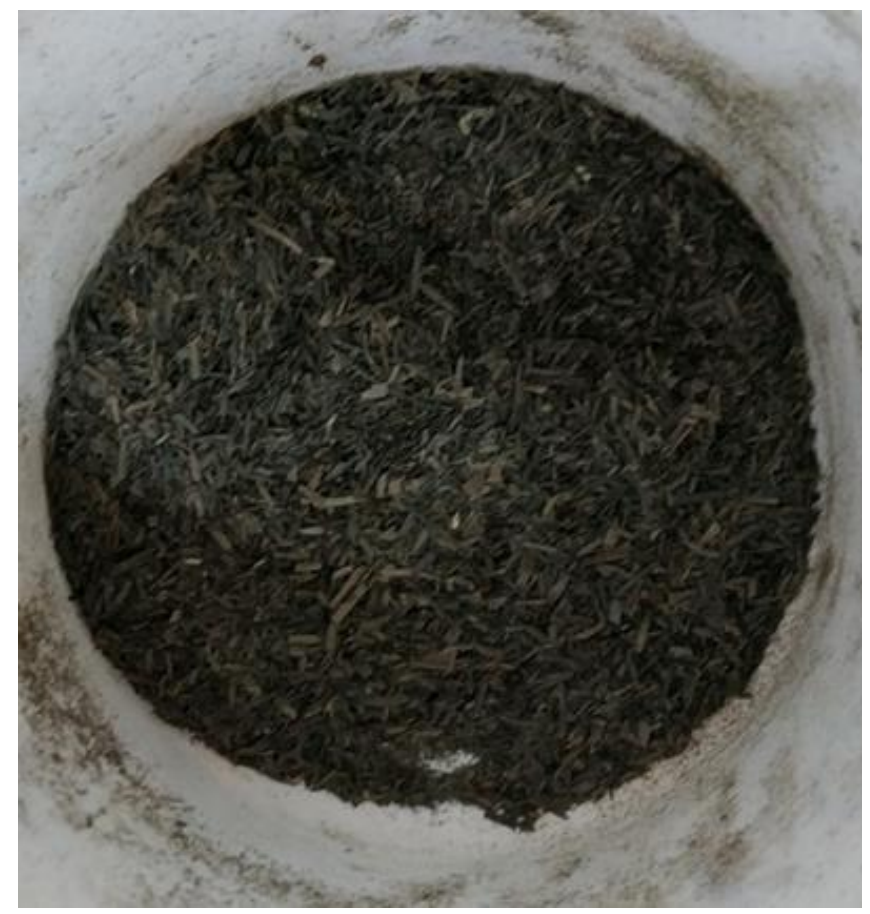

Рисунок 2. Камка після подрібнення 
Матеріали XXII Міжнародної науково-практичної конференції «Екологія. Людина. Суспільство» (м. Київ, Україна, 2021 р.)

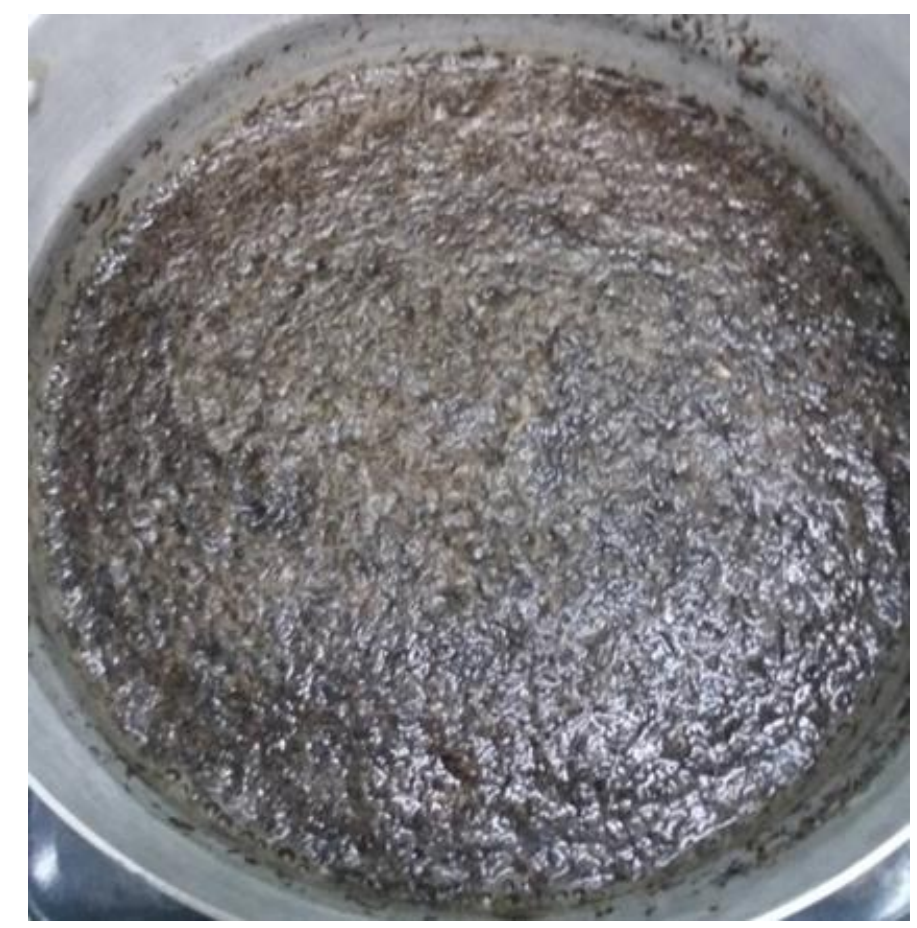

Рисунок 3. Розпущення камки у воді

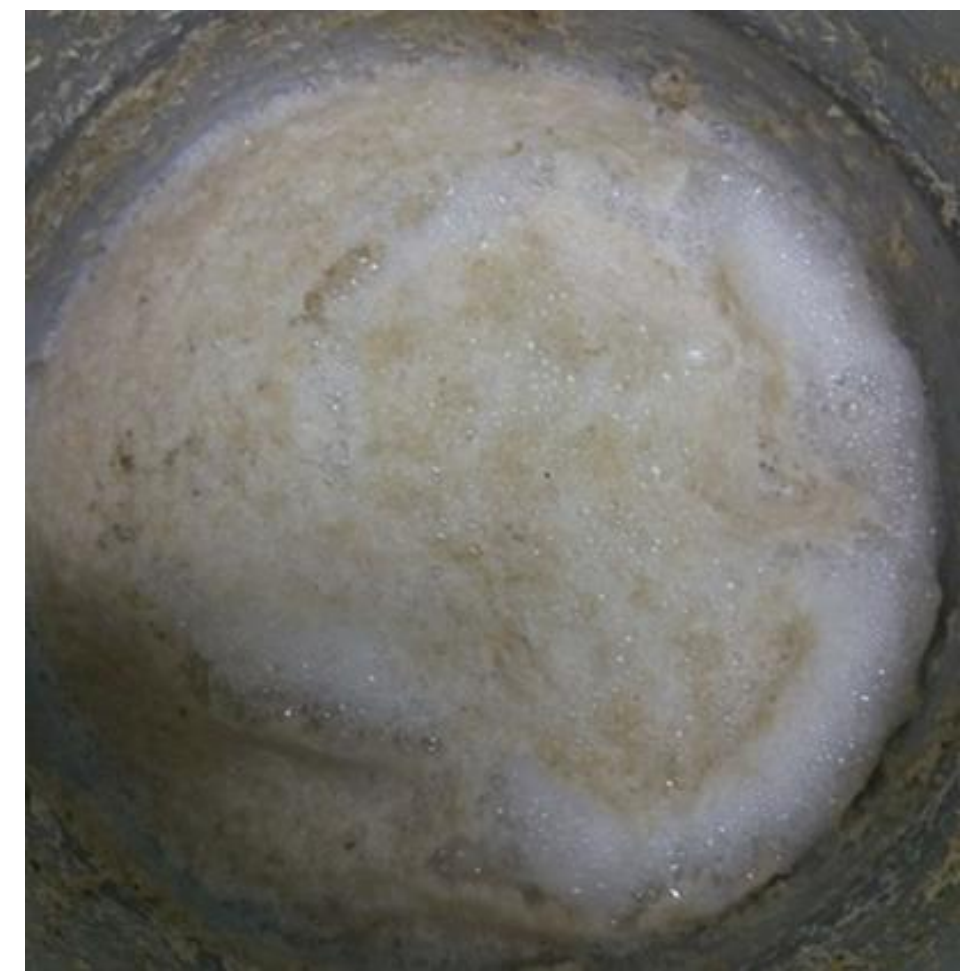

Рисунок 4. Паперова маса в процесі відбілювання «Ecology. Human. Society» (2021 Kyiv, Ukraine) 
Для отримання зразків паперу використовувалася спеціальна рамка з тонкою сіткою. Рамка занурюється у паперову суспензію, після осадження паперової маси зайва волога віджимається з використанням віджимної сітки. Отримані паперові зразки висушуються під пресом за температури $25^{\circ} \mathrm{C}$.

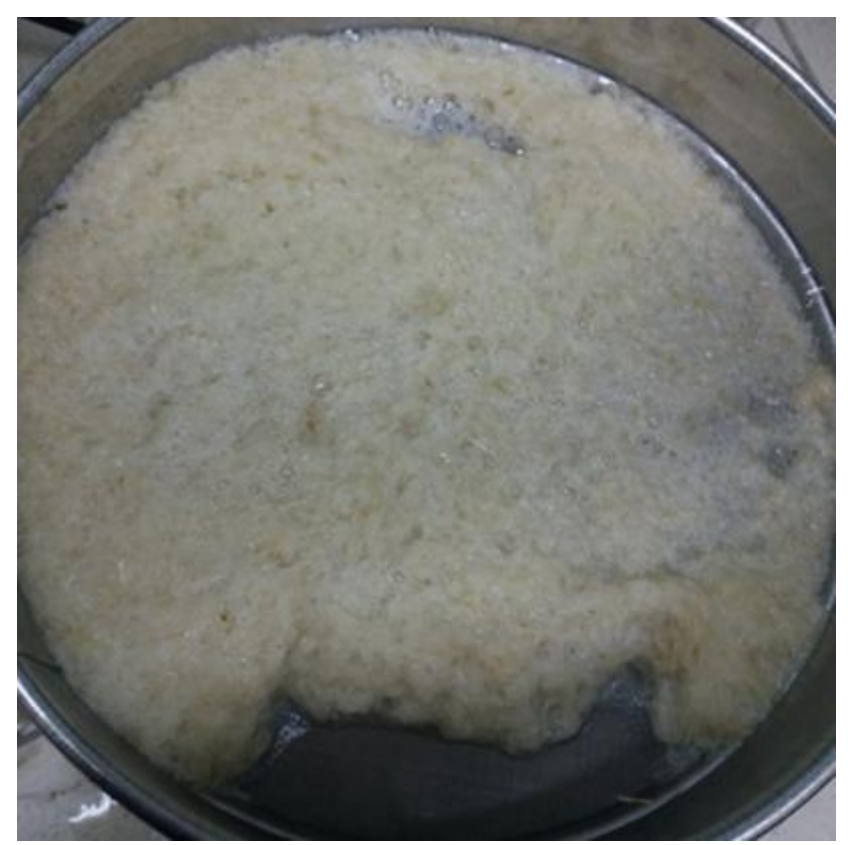

Рисунок 5. Промита та відбілена паперова маса

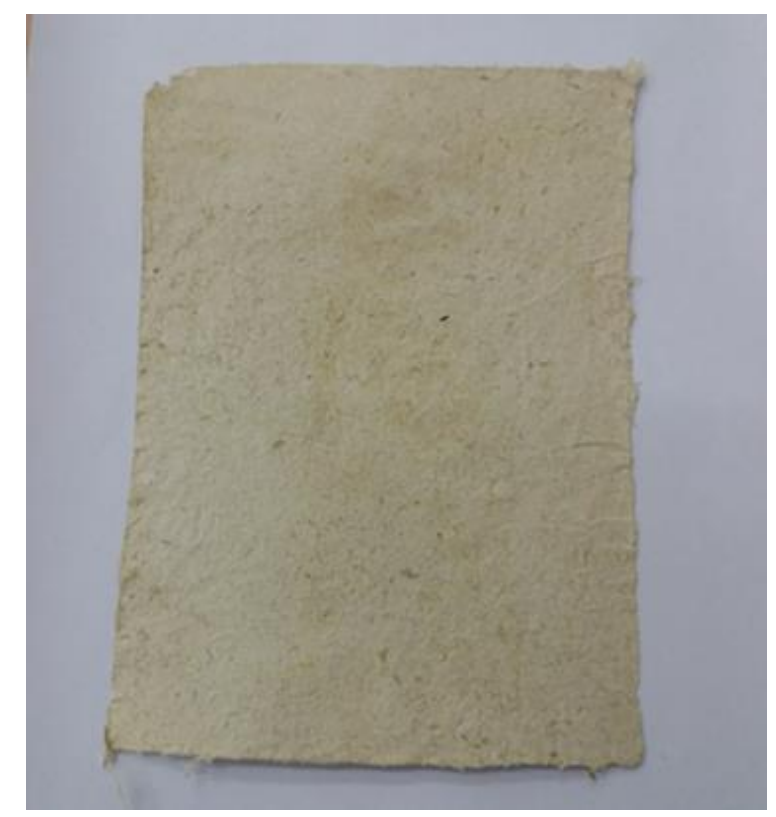

Рисунок 6. Зразок паперу з камки 
В ході лабораторного експерименту отримані зразки паперу з Zostera marina . B процесі виготовлення на першому етапі не вводилися додаткові компоненти, такі як каолін, глинозем, клеї, наповнювачі, тощо. Фізичні характеристики отриманих зразків було досліджено згідно відповідним методикам, наведеною у нормативному документі «ГОСТ 27015-86 Бумага и картон. Методы определения толщины, плотности и удельного объема».

За результатами досліджень отримані наступні характеристики зразків паперу (таб. 1).

Таблиця.

\section{Показники якості паперових зразків}

\begin{tabular}{|c|c|c|c|c|c|c|c|}
\hline $\begin{array}{l}\text { Темпера } \\
\text {-тура } \\
\text { варіння, } \\
{ }^{\circ} \mathrm{C}\end{array}$ & $\begin{array}{l}\text { Тривалі- } \\
\text { сть } \\
\text { варіння, } \\
\text { хв. }\end{array}$ & $\begin{array}{l}\text { Maca } \\
\mathrm{M}^{2}, \Gamma\end{array}$ & $\begin{array}{l}\text { Товщина } \\
\text { листа, мм }\end{array}$ & $\begin{array}{l}\text { Щільні- } \\
\text { сть, } \\
\Gamma / \mathrm{cm}^{3}\end{array}$ & $\begin{array}{l}\text { Питоми } \\
\text { й об’єм } \\
\mathrm{cm}^{3} / \Gamma\end{array}$ & $\begin{array}{l}\text { Вологі- } \\
\text { сть, \% }\end{array}$ & $\begin{array}{l}\text { Ступінь } \\
\text { проклеюванн } \\
\text { я, мм }\end{array}$ \\
\hline 90 & 90 & 20 & 0,2 & 0,1 & 10 & 1 & 1 \\
\hline 95 & 120 & 15 & 0,2 & 0,075 & 13 & 1,5 & 1 \\
\hline
\end{tabular}

За результатами проведених експериментів можна стверджувати, що використання у якості сировини целюлозно-паперової промисловості берегових покладів морської трави можливе та економічно доцільне.

3 таблиці 1 можна зробити висновок, що збільшення температури та тривалості обробки більше 90 хв. мало впливає на фізичні характеристики зразків паперу.

Хоча отримані зразки паперової продукції на теперішній момент не дуже відповідають вимогам до більшості паперових виробів за показниками маси, щільності, тощо, однак слід звернути увагу на те, що в ході експерименту до складу зразків не вводилися додаткові компоненти, які сприяють збільшенню маси, пружності, міцності та білизни паперу.

Відомо, що склад сировини суттєво впливає на масу отриманих зразків. Папір, отриманий з деревної сировини за умов однакової товщини буде мати більшу масу, ніж папір з альтернативної рослинної сировини.

Завданням подальшого дослідження є розробка складів волокнистих напівфабрикатів 3 додаванням необхідної кількості відповідних добавок, які б повністю відповідали вимогам паперової промисловості. Окремим пунктом можна вважати вивчення біологічних, антисептичних та фунгіцидних властивостей отриманих зразків з метою використання у якості пакувального матеріалу у фармацевтичній та харчовій галузі.

За результатами проведеної роботи було обгрунтовано можливість використання камки у якості альтернативної сировини целюлозно-паперової промисловості. 
Практичними результатами даної роботи буде створення ефективного способу одержання паперу з морських рослин, переважно Zostera marina, використання яких в якості сировини забезпечує здешевлення процесу виробництва, зменшення вирубки лісів а також можливість очищення засмічених викинутими на берег водоростями ділянок узбережжя й поліпшення їхнього екологічного стану.

\section{Література:}

1. Барбаш В. А. Інноваційні технології рослинного ресурсозбереження: Навчальний посібник. Київ: Каравела, 2017. 288 с.

2. Возможности переработки соломы для производства целлюлозы в Украине. - Режим доступу URL:https:/www.ifc.org/wps/wcm/connect/494b46804090

3. Трембус І.В. Пакувальній папір із стебел соняшнику / I. В. Трембус // Молодий вчений. - 2016. - № 3. - С. 280-284. - Режим доступу: http://nbuv.gov.ua/UJRN/molv_2016_3_66

4. Завод по производству целлюлозы из конопли - Режим доступу http://tku.org.ua/

5. Папір з опалого листя: технологію запустили у виробництво - Режим доступу https://uain.press/news/papir-z-opalogo-lystya-tehnologiyu-zapustyly-u-vyrobnytstvo-1357234 4.

6. Кизиветтер И.В., Грюнер В.С., Евтушенко В.А. Переработка морских водорослей и других промысловых водных растений. - М.: Пищевая промышленность, 1967. - 381 с. Режим доступу https://findpatent.ru/patent/230/2302746.html

7. Мостика К.В., Коптюх Л.А., Осика В.А. Аналіз вимог до паперу для пакування харчових продуктів // ТАРП. 2015. №4 (26). - Режим доступу URL: https://cyberleninka.ru/article/n/analiz-vimog-do-paperu-dlya-upakuvannya-harchovihproduktiv

8. Иванов С.Н. Технология бумаги. Изд. 3-е., 2006, 696 с.

9. Целлюлоза, получаемая из водорослей, экологическая альтернатива традиционному производству. Новости Андалусии - Режим доступу http://novostiandalusii.com/cellulozavosorosli-sevilla-ekologia/ 